European Journal of Archaeology

Manuscript received 18 February 2019, revised 28 May 2019, accepted

\title{
Bog Bodies in Context: Developing a Best Practice Approach
}

\section{Henry Chapman ${ }^{1}$, Roy VAn BeEK ${ }^{2}$, Ben GeareY ${ }^{3}$, Ben Jennings ${ }^{4}$, DAVID SMith ${ }^{1}$, Nina Helt NiElSEN $^{5}$ AND ZENA ZeIN Elabdin ${ }^{1}$}

${ }^{1}$ Department of Classics, Ancient History and Archaeology, University of Birmingham, UK

${ }^{2}$ Department of Environmental Sciences, Wageningen University, The Netherlands

${ }^{3}$ Department of Archaeology, University College Cork, Ireland

${ }^{4}$ School of Archaeological and Forensic Sciences, Univeristy of Bradford, UK

${ }^{5}$ Museum Silkeborg, Denmark

Bog bodies are among the best-known archaeological finds worldwide. Much of the work on these often extremely well-preserved human remains has focused on forensics, whereas the environmental setting of the finds has been largely overlooked. This applies to both the 'physical' and 'cultural' landscape and constitutes a significant problem since the vast spatial and temporal scales over which the practice appeared demonstrate that contextual assessments are of the utmost importance for our explanatory frameworks. In this article we develop best practice guidelines for the contextual analysis of bog bodies after having assessed the current state of research and presented the results of three recent case studies including the well-known finds of Lindow Man in the United Kingdom, Bjaldskovdal (Tollund Man and Elling Woman) in Denmark, and Yde Girl in the Netherlands. Three spatial and chronological scales are distinguished and linked to specific research questions and methods. This provides a basis for further discussion and a starting point for developing approaches to bog body finds and future discoveries, while facilitating and optimising the re-analysis of previous studies, making it possible to compare deposition sites across time and space.

Keywords: bog bodies, Europe, landscape, scalar analysis, peatlands, site location

\section{INTRODUCTION}

The term 'bog bodies' has been in use since the 1870s for the often well-preserved human remains found in peat bogs across northern Europe (van der Sanden, 1996, 2013). The conditions of their burial environment can support the preservation of soft tissues that are not 
normally preserved on archaeological sites (Brothwell \& Gill-Robinson, 2002). This results in significant opportunities for acquiring detailed information about the lives and deaths of the individuals. Consequently, most of the work on bog bodies has focused on forensics, leading to substantial knowledge gain. However, the study of their landscape context constitutes a hitherto unexploited potential for increasing our knowledge of bog bodies and their depositional history. Most studies are site-based and fail to incorporate detailed assessments of the environmental setting of the finds, both with regard to the 'physical' and 'cultural' landscape (Chapman, 2015). Moreover, no attempt has been made to produce best practice guidelines. These are significant problems: the vast spatial and temporal scales over which the burial practice appeared clearly show that detailed contextual assessments are of the utmost importance for our explanatory frameworks. A new, more standardized approach is important for three reasons: (1) to ensure future discoveries are adequately investigated; (2) to facilitate and optimize the re-analysis of known findspots and; (3) to make it possible to compare deposition sites across time and space.

In this article, we develop best practice guidelines for the contextual analysis of bog bodies, achieved in three steps. We first analyse the current state of research, which provides insights into methods that have been successfully applied so far and highlights significant research deficits that need to be tackled. We then present three recent case studies that illustrate the potential of a landscape-based approach. They include some of the best-known bog bodies of Europe, including Lindow Man in the United Kingdom, Tollund Man and Elling Woman in Denmark, and Yde Girl in the Netherlands (Figure 1). The results feed into the best practice guidelines that we propose here. Three spatial and temporal scales are distinguished and linked to specific research questions and methods, which we hope will form practical guidelines for future fieldwork and analysis.

\section{CurRent State of RESEARCH}

The significant interest in European bog bodies stems largely from the often exceptional levels of preservation that includes soft tissue, hair, and skin, alongside internal organs and stomach contents. Such preservation provides extraordinary potential for the study of the forensic aspects of these individuals. For many bodies, the ability to identify injuries that would not normally be visible on the skeleton gives a tantalising glimpse into their final moments. Many 'early' bog body finds have been lost due to a variety of factors (Cowie et al., 2011), and consequently most attention has been paid to discoveries made since the late nineteenth and early twentieth centuries. Some of these 'old' finds have recently been re- 
examined (e.g. van der Plicht et al., 2004; Gill-Robinson, 2005; Asingh \& Lynnerup, 2007). In some regions, peat cutting has long ceased, and no finds have been made in decades (e.g. in the Netherlands: van Beek et al., 2015). In others, there have been new discoveries in recent years, most notably in Ireland (e.g. Kelly, 2006, 2012), but also in Germany (Bauerochse et al., 2018).

Extensive research on the landscape settings of bog bodies, defined for our purposes as including both the environmental and cultural contexts at the time of deposition, has been limited. A small number of multidisciplinary studies, with their own specific aims and methods, has focused on the palaeoenvironmental analysis of individual sites. Good examples are those of Old Croghan (Plunkett et al., 2009) and Tumbeagh, both in Co. Offaly in Ireland (Bermingham \& Delaney, 2005), and Uchte in lower Saxony in Germany (Bauerochse et al., 2018). In general, these site-based studies incorporate the detailed analysis of multiple environmental proxies, such as pollen, plant macrofossils, testate amoebae, and beetles to characterize the depositional site of bodies in the context of broader processes of landscape change. Additionally, Andreas Bauerochse and Andreas Niemuth (2012) developed a 3D landscape model of the Großes Moor at Uchte (Germany), whereas Henry Chapman (2015) modelled archival data relating to Lindow Moss (United Kingdom). Jes Martens (1994) published an overview of the Iron Age stronghold of Borremose (Denmark), using mainly archaeological data. The latter comprises a concise overview of the wider cultural landscape setting, with several bogs rich in archaeological finds, including at least three bog bodies and the well-known Gundestrup cauldron (Figure 2). Recently, Christina Fredengren (2018) has also used multiple datasets to analyse the deposition of bog bodies in Sweden.

Besides the site-based publications mentioned above, various regional overviews of bog body sites are available (e.g. van der Sanden, 1996; Ravn, 2010, 2011; Hesse et al., 2010; Burmeister, 2013). These start from an archaeological perspective and share a focus on the history of the discoveries, forensics, and explanatory models. Occasionally, some information is given on the landscape setting. Stefan Burmeister (2013), notably, examined the distribution of bog bodies across northern Europe in relation to a number of factors, including the size of the bogs in which the bodies were found and their position in relation to the bog edges. Morten Ravn (2011) stressed the importance of incorporating data on contemporaneous settlements and cemeteries, but unfortunately did not put this into practice. One specific observation made in relation to the landscape setting of bog bodies, particularly in Denmark, is that some of them were probably placed in earlier peat cuttings (e.g. Asingh, 2007; Fischer, 2012). 
The detailed site-based studies discussed above mark a modest shift in research into bog body sites, with the importance of palaeoenvironmental analyses recognized, not only in terms of establishing the environmental context but also highlighting the contribution these data can make to aspects of cultural interpretation (see Gearey \& Chapman, 2004). Nevertheless, there are significant methodological and theoretical problems that still need to be addressed. Most of the work so far has been limited in scope, both spatially and/or chronologically. Many studies focus on what can be defined as the local level, that is, the findspot itself and its immediate vicinity. This probably stems from the fact that bog bodies are often perceived as more or less exceptional phenomena (e.g. Glob, 1969) and hence are studied in their own right. Arguably, another aspect is that the context of discovery may be implicitly viewed as providing little information aside from being a 'wet bog'. Yet, as we shall see, bog landscapes vary between and within sites with respect to vegetation, relative surface wetness, etc.

The chronological focus of many studies is generally on the 'deposition' event itself instead of the potential of longer-term perspectives offered by the character of the landscape and change within it derived from palaeoenvironmental evidence, although information from these data may be implicit in certain interpretative frameworks (e.g. Kelly, 2006, see below). It is indeed important to realize that these finds, like all archaeological material, can only be understood in a larger social, spatial, and chronological context. Gaining detailed insights into diachronic palaeoenvironmental changes can lead to a better understanding of the deposition sites, especially the interplay between peatland dynamics, specifically palaeohydrological fluctuations which may be related to climatic changes, as Kelly (2006) shows in his interpretation of later prehistoric Irish bog bodies. Hydrological data derived from testate amoebae analyses have allowed Gearey and Caseldine (2007) to argue that patterns of prehistoric activity, as reflected in the construction of sites on the peatland, were closely related to shifts in surface wetness. There is no corresponding information for recent later prehistoric Irish bog body finds other than Old Croghan Man (Plunkett et al., 2009). Human land-use patterns derived from pollen analyses also potentially contribute to these discussions although we encounter theoretical as well as methodological issues when linking archaeological 'events' such as the deposition of a body to less chronologically 'exact' palaeoenvironmental events such as changes in land-use.

When considering the socio-cultural context of the bog body practice, it should be realized that various types of wetlands, amongst them peatlands, were recurrently used for deliberate deposition of carefully selected objects. While there is considerable variation in the 
ways in which such practices were enacted at different sites, for many, these practices were conducted in 'natural' places for millennia, an aspect that indicates the importance of these areas for (pre)historic communities (e.g. Bradley, 2000). The selective deposition of objects (see Needham, 1988, Fontijn, 2002) had motives often regarded as 'ritual', as frequently suggested for the bog body phenomenon. However, variations in the details relating to bog bodies highlight the risk of conflating the use of the term for both their description and interpretation. Clearly, there is a need for greater levels of contextual information. Hence, any attempt at interpretation should incorporate a thorough analysis of the patterns of wetland deposition within the context of other archaeological material (Becker, 2013) and broader contemporary social and cultural patterns. In this respect, it is striking that few detailed site distribution maps are available depicting the findspots of bog bodies, settlements, cemeteries, field systems, and other cultural phenomena, the Borremose region being one of the very few exceptions (Figure 2). It is clear that singling out bog bodies as a specific find category is misleading, and that making distinctions between wetlands (serving 'ritual' purposes) and drylands ('profane' use) is not useful if we want to contextualize both environmentally and culturally, and understand past deposition practices. We are dealing with traditions that, at least in their appearance, share similarities over millennia and across vast areas. However, there are also clear differences between sites, and we need to anticipate that underlying motives and meanings may have been diverse and dynamic. This makes contextual analyses even more important. To illustrate this, we present three recent case studies that highlight the potential of a landscape-based approach to the study of bog bodies.

\section{Case Studies}

\section{Lindow Moss (United Kingdom)}

Lindow Moss is a peatland in Cheshire where four discoveries relating to probably two or three (partial) bog bodies have been made. The first, a cranium found in 1983 (Lindow I; Brothwell, 1986), was followed by the excavation of a body in 1984 (Lindow II; Turner, 1986). Subsequent discoveries of body parts were made in 1987 (Lindow III, near Lindow I) and 1988 (Lindow IV, probably associated with Lindow II; Turner, 1995). The analysis of the most complete body, Lindow II (more commonly known as Lindow Man), revealed a complex set of injuries resulting in his death, including blows to the head, garrotting, and a slit throat (West, 1986). At the time of discovery, samples for palaeoenvironmental analysis were taken from the findspot. Their analysis led to the conclusion that Lindow II was deposited in a pool of water (Buckland, 1995), the bog having become wetter shortly before 
deposition (Barber, 1995). No wider assessment of the landscape context was undertaken at the time of discovery but in the 1990s a borehole survey across Lindow Moss provided stratigraphic data (Leah et al., 1997).

Chapman (2015) modelled the data collected in the 1990s to reconstruct the landscape at the time of deposition. He concluded that the locations of the depositions were close to the very centre of the peatland in the Iron Age. Coupled with the earlier suggestion that the landscape was becoming wetter at the time, it is likely that the area had become increasingly inaccessible and that the deposition of the bodies required significant effort. A subsequent programme of gridded borehole excavation across the whole of Lindow Moss confirmed this interpretation, and has identified areas of peat near the location where Lindow II was discovered that may include contemporaneous and more recent deposits (Figure 3).

Pollen analysis demonstrated that the wider landscape around Lindow Moss was subject to increased woodland clearance throughout the Iron Age and into the RomanoBritish period. The data indicate an expansion of human activity indicators, such as Plantago lanceolata, and open pastoral environments (Birks, 1965; Oldfield et al., 1986; Branch \& Scaife, 1995). They are the strongest indication of human activity in the area around Lindow Moss, whereas the archaeological evidence within the locality is relatively slim. Finds from the bog itself include earlier Bronze Age artefacts (Cheshire HER1472/0/0) and a Bos jawbone (Cheshire HER1472/0/1), in addition to anecdotal reference to an undated trackway structure on its south-western side (Cheshire HER1472/0/2; Norbury, 1884). ${ }^{1}$ Prehistoric copper mines are found on Alderley Ridge, approximately $3 \mathrm{k} \mathrm{m}$ to the south-east of the site. Evidence for wider later prehistoric activity centres on the Mid Cheshire Ridge to the southwest, including a cluster of hillforts. However, these are likely to have been abandoned by the time of Lindow II's deposition.

The wetland context of the Lindow bodies might emphasize the relative inaccessibility of the findspots. In contrast, the wider dryland landscape consisted of largely treeless agricultural land. These data can be variously interpreted. For example, if the contemporary mire surface was very wet, it is likely that the people responsible for the deposition had intimate knowledge of the local environment. The apparent lack of archaeological structures close to the findspots confirms that access must have been on foot without the benefit of a trackway. The character of the wider cultural landscape is more

\footnotetext{
${ }^{1}$ All Cheshire HER data available from Revealing Cheshire's Past database: http://rcplive.cheshiresharedservices.gov.uk/monumentsearch.aspx
} 
difficult to establish in terms of the distribution of archaeological sites with respect to the vegetation, although the evidence for an increasingly open grassland with possible indicators of pastoral farming suggests a largely domesticated locale. Other aspects include the fact that an open landscape has implications in terms of visibility from the dryland, potentially significant for any observers or audiences to the killing and deposition of Lindow Man.

\section{Bjældskovdal (Denmark)}

Bjældskovdal is a valley wetland on the eastern edge of what is now $\mathrm{B} ø$ lling Lake in central Jutland, where three bodies have been found in close proximity. The first discovery was of a body in 1927, but it was unfortunately not recovered from the bog (van der Sanden, 1996). The discoveries of Elling Woman in 1938 and Tollund Man in 1950 followed. These two bodies had clearly been hanged, and the careful excavation of the well-preserved Tollund Man showed that he had afterwards been gently placed in the bog in a sleeping position with his eyes and mouth closed. Stratigraphic observations at the find locations of Tollund Man and Elling Woman indicated that these bodies had been placed in old peat cuttings, which also agrees with the findings of prehistoric wooden spades close to the two bog bodies at approximately the same find depth (Fischer, 2012).

In 2017, a new field project was started by the University of Birmingham in collaboration with Museum Silkeborg. Its aim is to reconstruct the topography of the sandy, pre-peat land surface and to establish the potential for the survival of organic deposits. Fortyseven boreholes were excavated, aligned in three transects across Bjældskovdal, encompassing the approximate findspots of Tollund Man and Elling Woman. During the borehole survey, a maximum depth of $1.55 \mathrm{~m}$ of peat was identified within the boreholes, the average being less than $0.5 \mathrm{~m}$. However, it is known that peat cutting in the first half of the twentieth century removed a 2-4 m-thick peat layer from practically the entire surface of Bjældskovdal. The profiles revealed a relatively flat-bottomed valley with a narrow channel on its northern side that deepened towards the west.

Establishing the three-dimensional position of the bodies in relation to these profiles is problematic for two reasons. First, the archival data is incomplete and, in some cases, contradictory. Second, the positioning within ancient peat cuttings means that calculating the likely elevation range of the peatland surface requires some calibration. For Elling Woman, contemporary reports indicate that her head lay approximately $36 \mathrm{~cm}$ from the sandy base of the peat. The skin wrapping was just $15 \mathrm{~cm}$ above the base of the bog, $60 \mathrm{~cm}$ to the south (reproduced in Fischer, 2012: 84). Absolute basal elevations within the potential area of the 
findspot of Elling Woman (based on Fischer, 1980) range between $67.35 \mathrm{~m}$ and $68.43 \mathrm{~m}$ asl. Therefore, it is likely that the position of the body was around $68 \mathrm{~m}$ asl. For Tollund Man, establishing the likely elevation of the body is more difficult. Estimates calculated from notes by Jørgen Troels-Smith in 1952 (National Museum Archive Number A4020) in relation to the adjacent peat section indicate an elevation for the body of between 68.40 and $69.50 \mathrm{~m}$ asl. Currently, only Tollund Man has been re-dated using the newest methods (405-380 cal BC); but, based on current knowledge, it appears that Elling Woman was deposited in Bjældskovdal slightly later (200 years later at most; Nielsen et al., 2018). Because of the general contemporaneity of the two bog bodies, one might assume that the lower elevation is more likely, although the possibility for variations in bog surface elevation from ancient peat cuttings should be taken into account. Stratigraphic indications suggest such cuttings to be 40 $\mathrm{cm}$ deep, and it seems that the maximum elevation of the bog surface at the time was about $70 \mathrm{~m}$ asl.

The elevation of the bodies in relation to the bog surface level, combined with their horizontal positioning, provides the potential to explore factors such as accessibility and distance from the bog edge at the time of deposition (Figure 4). The horizontal positioning of Tollund Man can be calculated from archival data from the environmental work of TroelsSmith (1952), placing Tollund Man towards the centre of the peatland. If the surface of the bog was at around $70 \mathrm{~m}$ elevation, the full width of the bog would be $130 \mathrm{~m}$. This would require travel across the bog from the nearest dryland over $65 \mathrm{~m}$ from either side. If the surface of the bog had been at $68 \mathrm{~m}$ elevation (corresponding with the minimum surface elevation of the peat cutting containing the body of Elling Woman) then the total width of the bog would have been considerably narrower at $70 \mathrm{~m}$. Due to the shape of the valley floor, a difference in elevation of just $2 \mathrm{~m}$ has a dramatic impact on the accessibility of the bog.

Roughly contemporary finds from the area of the bog include several wooden spades of which two were found a few metres from Tollund Man, and one close to Elling Woman. Two parallel rows of Quercus stakes, probably the remains of a corduroy trackway, were also discovered. Unfortunately, the precise position of this structure is not known, but they crossed the bog with stakes positioned approximately every metre, with a little less than $2 \mathrm{~m}$ between the two rows. Radiocarbon dating of the only preserved stake indicates that the trackway was constructed around 793-486 BC (95.4\% confidence interval; recalibration on the average of $2500 \pm 40$ BP as reported in van der Plicht et al. (2004), with OxCAL v.4.3.2 (Bronk Ramsey, 2009) using the IntCal13 calibration curve (Reimer et al., 2013)). While this one stake pre-dates the bodies, the trackway may still have been in use when the bodies were 
placed in the bog. No Early Iron Age settlement, graves, or field systems have been found close enough to Bjældskovdal to suggest a direct link with the bog bodies, but human activity in the broader region at this time is well attested.

It is clear that the location chosen for the deposition of Tollund Man (and probably the other bodies) was in the centre of the bog, broadly equidistant from the dryland to the north and south. It is uncertain what the hydrological status of the bog was at the time (in terms of surface wetness) and the relationship between this and Iron Age peat cutting, or the context in terms of wider chronological and spatial patterns of environmental change is also uncertain. Regardless, the profile of the bog indicates that any increased wetness would have resulted in considerable lateral spread. Ongoing archive studies and analyses of samples taken from a surviving peat baulk may provide more insight into the environmental and landscape context of the three bog bodies.

\section{Yde Girl (The Netherlands)}

Yde Girl gained worldwide recognition when her face was reconstructed at Manchester University in 1992 (van der Sanden, 1994). She was found in 1897 by two labourers in a small bog south of the village of Yde (van der Sanden, 1990: 81-83). The bog body surfaced when the labourers were extracting peat using dredging poles, at a depth of approximately one metre. The remains belong to an approximately 16-year old girl with long hair, the right half of which was probably cut off. She was dressed in a heavily-worn woollen cloak. A braided woollen cord with a sliding knot around her neck was probably used to strangle her. A series of $\mathrm{AMS}{ }^{14} \mathrm{C}$ dates of samples from hair, cloak, and cord (van der Plicht et al., 2004: 486-87), which have been recalibrated for the present study, place her death between 42 cal $\mathrm{BC}$ and cal AD 59 (95.4\% confidence interval).

The site was reconstructed in the 1990s by a combination of written documents, cartographic evidence, and oral history (van der Sanden, 1990, 1994). Late nineteenthcentury topographic maps show various T-shaped and right-angled peat reclamation pits scattered over a large heath area. There has been some debate as to the exact findspot, but the most likely site is the north-easternmost reclamation pit. Since the late 1920s, the area was gradually turned into agricultural land. In the 1970s, the pit was filled in with sand and a field ditch was dug through its centre, the site being subsequently used as arable land. The location is still clearly visible as a wet depression. In 1995, students of Groningen University conducted a small-scale field survey by means of borehole excavation, and a palynological analysis was carried out (Bandel et al., 1995; Bottema, 1995). The data indicated the 
depression to be $1.8 \mathrm{~m}$ deep at the maximum, with Late Glacial or Early Holocene peat in the lower part of the profile.

In 2017-2018, the Yde site was re-investigated by an interdisciplinary team from Wageningen University and Research Centre in order to reconstruct the physical and cultural landscape context at the time of deposition (van Beek et al., 2019). The analysis centred on the site itself and its wider environment, the latter consisting of a study area of $14 \times 11 \mathrm{~km}$ around the findspot. The study comprised physical geographical, palaeoecological, and archaeological components. The geographical elements consisted of the creation of an up-todate geomorphological map of the wider study area, combined with a Ground Penetrating Radar (GPR) survey and coring at the findspot. The palaeoecological investigation focused on reconstructing the vegetation in the wider study area, based on a detailed inventory of existing palynological data in and near the area under study. The archaeological component centred on reconstructing the cultural landscape in the later Iron Age and early Roman period by compiling a thorough inventory of archaeological sites (Figure 5).

Results of the study demonstrate that Yde Girl was probably deposited in a small, wet depression (possibly a pingo remnant) with a diameter of approximately $30-40 \mathrm{~m}$ and a depth of about $2 \mathrm{~m}$. This small bog lay within a relatively heterogeneous landscape dominated by a series of moraine ridges, most importantly the large Hondsrug ridge about $3 \mathrm{~km}$ to the east, and low-lying plains and valleys in between. The vegetation was relatively open, of mosaic character, consisting of heathland, relict forest, arable fields, and pasture, and was heavily influenced by human activity. The landscape was dotted with small hamlets consisting of a few farmsteads, cemeteries, 'Celtic' field systems, and other deposition sites. These show that the findspot was by no means remote or isolated, but very much part of an anthropogenic landscape.

Compared to the work on Lindow and Bjældskovdal, the methodology applied in the recent Yde case study stands out for its interdisciplinary approach and combination of different spatial research scales. The most detailed new knowledge was gained from the reconstruction of the cultural landscape in the wider study area, enabled by the availability of a large archaeological dataset in combination with an inventory of extant palynological evidence. The Yde region is a typical example of a Dutch reclamation landscape, heavily affected by humans. Even though the Yde findspot itself no longer contains significant peat remains, there are various pingo scars scattered over the wider area that probably contain better-preserved sediments and may form targets for additional future palaeoenvironmental analysis. 


\section{Proposed Methodology}

Based on our assessment of previous work and the experiences gained during the recent and ongoing projects in the United Kingdom, Denmark and the Netherlands, best practice guidelines can be proposed for future research on the environmental and cultural context of European bog bodies. Central to this is the realisation that different research questions need to be answered on different spatial and chronological scales, using bespoke methodologies that draw from cultural and scientific approaches (Table 1). We suggest the following as a 'best case' framework that can be tailored for particular situations. Raising awareness of where within the research framework the investigation is positioned (including possibilities to expand) would be extremely valuable. For working purposes, we define context in terms of archaeology and palaeoenvironment, although we recognize that these categories are interrelated. Similarly, we identify three nested scales (spatial and chronological) relative to the findspot: micro-, meso- and macro-scale (see Table 1 and Figure 6). The relationship between these scales is not unproblematic or linear (see below); aspects of each scalar component might be adopted depending on factors such as previous research. We are aware that not every study can work on all scales and use all proposed methods, as all contexts are different and available resources vary.

\section{Micro-scale resolution}

The micro-scale can be defined as restricted to the immediate find location, measured in terms of a few square metres (e.g. the original investigations of Lindow Man) around the position of the body. This should be regarded as the very minimum scale of analysis for in situ finds, providing local contextual data only. The critical aspect is determining the character of this depositional environment (e.g. pool, peat cutting), the development of the associated bog surface across time scales (minimum 10 years) in relationship to the age of the body and any associated archaeological finds. For most bog bodies where palaeoenvironmental analyses have taken place, it is generally at this resolution that the work was conducted. For some sites, the surviving deposits directly associated with the bodies will be missing, although adjacent deposits (e.g. at Lindow Moss) provide the potential for detailed analysis. Bermingham and Delaney (2006) describe an exemplary approach to the excavation and sampling of the Lemanaghan Bog Body (Tumbeagh, Co. Offaly in Ireland), building on the approach developed for Lindow Man (Turner, 1986) and allowing optimal sampling, excavation, and analyses on the micro-scale. The strategy developed by 
Bermingham and Delaney (2006) included the establishment of 'buffer zones' around the remains exposed on the cutover surface of the peatland, followed by cleaning the area around the body $\left(270 \mathrm{~m}^{2}\right.$ in total), concentrating on the direction in which peat cutting machinery tended to move material. The excavation of small circular test pits $(0.10 \mathrm{~m}$ diameter, $0.30 \mathrm{~m}$ deep) around the exposed body allowed the extent of the remains to be better defined, leading to the isolation of a block of peat containing the surviving body $(1.2 \mathrm{~m} \times 0.6 \times 0.5 \mathrm{~m})$, which was lifted, packed, and excavated in the laboratory. Excavation of in situ remains in laboratory conditions must be regarded as a key aim, permitting understanding of the microstratigraphy of the peat in relation to the human remains. Direct lifting of remains should be avoided if possible, as this is very likely to result in the loss of potentially crucial stratigraphic data as well as excluding the possibilities of sub-sampling peat samples in intimate association with the body.

From a palaeoenvironmental perspective, the focus should be on understanding the immediate depositional environment of the body, including the nature of the contemporaneous bog surface and that associated with the depth of the remains. Such data can be gathered in part stratigraphically from excavations (where possible), as well as adjacent sections (e.g. drain faces) if available, and from boreholes. In order to understand the local environmental context, a range of palaeoenvironmental analyses will generally be required. As a minimum, this should include plant macrofossils, beetles and potentially other proxies, specifically testate amoebae to determine the wetness of the bog surface, in the case of ombrotrophic peat deposits. Other relevant analyses might include determining the ash content of the peat (Bermingham \& Delaney, 2006: 38). It is important that sampling strategies be developed in advance of excavation, in consultation with the relevant specialists. Different proxies require specific practical approaches; sampling for microfossils would usually be facilitated via monolith sampling, while bulk samples for beetles and plant macrofossils require the development of a bespoke strategy derived from an understanding of the particular stratigraphic context of the body. The key point is the development of an integrated approach to palaeoenvironmental analyses and sampling at the earliest opportunity and preferably the presence of the relevant specialists during excavation.

Understanding the bog surface, derived from stratigraphy and the palaeoenvironmental proxies, has particular implications for factors such as the burial environment (which can be compared with forensic evidence for deposition) and the ease or difficulty of movement at the location itself. Given observations, particularly in Denmark, of bodies being placed in peat cuttings, there is considerable potential for discrepancies between 
the dates of the bodies and the dates of the underlying peat surface. Exposed sections can provide context, but in their absence a gridded borehole survey will be required to assess the stratigraphic context of the local area, potentially with additional palaeoenvironmental analyses and radiocarbon dating. The possibility that deposition could relate to contemporary environmental change, such as increased bog surface wetness, highlights the need to undertake detailed, high-resolution analysis of palaeoenvironmental samples contemporary with, and directly pre-dating, the body.

Detailed analysis of archaeological observations related to the body and findspot, including forensics (evidence of peri- and post-mortem impacts) and associated finds, give insights into the context of the find and the preservation conditions of the body compared with stratigraphy. Best practice should include block lifting of the remains if possible, allowing detailed excavation in the laboratory (see Bermingham \& Delaney, 2006). At the very least, a survey of the immediate area of the find for further archaeological remains and recovery of samples, if appropriate, should be undertaken.

The chronological programme must establish the age of the body itself, taking into account the issues around establishing a reliable date for previous bog bodies. Single radiocarbon determinations are probably insufficient. In terms of the palaeoenvironmental sequences, the radiocarbon programme should be sufficiently nuanced to construct a chronology of the stratigraphic and biostratigraphic changes established by the fieldwork and palaeoenvironmental programmes. Multiple dates and analyses of multiple peat fractions (Chapman \& Gearey, 2013) may be necessary to ensure a robust chronology and to investigate any discrepancies between the date of the body and its associated context (see the Lindow Man debate: Barber, 1995; Buckland, 1995).

\section{Meso-scale resolution}

Challenges and opportunities at the meso-scale, within the wider locality of the findspot (i.e. within a radius of 10-100 m), are slightly different. In previous research, this scale of investigation is perhaps the most under-studied. The purpose of using this spatial scale is to establish the location of the body within the context of the peatland system. This, for example, includes the identification of pools, wetter/drier areas, drainage channels, or ancient peat cuttings. In addition to broadening the spatial resolution of analysis, it should expand the chronological focus to the scale of hundreds of years to facilitate the interpretation of landscape changes over multiple generations (and also reflect the precision of many of the dates obtained for bog bodies). 
In order to achieve this, a detailed stratigraphic analysis of these areas of the bog is needed. Where appropriate this can be combined with geophysical methods (e.g. GPR) to establish the shape of the pre-peat topography (see Chapman \& Gearey, 2013) and provide data for the modelling of stratigraphic layers within the bog. There remain challenges in identifying waterlogged archaeology within peatlands by geophysics due to a lack of physical contrasts (e.g. Clarke et al., 1999) and a variety of different techniques have been applied to address this (e.g. Schleifer et al., 2002). However, it has been noted that GPR has the greatest potential for these environments, with some success in identifying in situ sites (Armstrong et al., 2018), but that this is dependent on chemistry and peat preservation. Remote sensing provides the possibility of obtaining continuous stratigraphic data across a bog, and this can be validated through borehole stratigraphic analysis.

Dates for the onset of wetland growth from basal deposits across the bog can give evidence of its chronological development, in addition to providing indications, through modelling, of the processes that influenced its formation (see Chapman \& Gearey, 2013). Establishing the palaeohydrological status of the peatland, through testate amoebae, plant macrofossils, and techniques such as humification analyses, is of particular relevance at this scale. These data are significant for assessing the relative wetness of the peatland at the time of body deposition, but also for identifying any longer-term fluctuations in hydrology, including at or just before the event in question. Kelly (2006) has hypothesized that later prehistoric Irish bog body killings may relate to sacrificial rituals following episodes of crop failure potentially associated with climatic deterioration. In theory, such palaeoenvironmental 'events' can be identified from pollen and palaeohydrological proxies. Although demonstrating a causal link with the deposition of a body is theoretically and methodologically challenging, close resolution sampling and the construction of robust archaeological and palaeoenvironmental chronologies is the only way to test these hypotheses.

Through such analysis, coupled with palaeoenvironmental study, it is possible to determine differences in the bog surface at different times as this has implications for factors such as movement within and across the wetland. Furthermore, this can also provide information relating to the distance from the bog edge at the time of the body deposition.

Other archaeological finds and structures from the locality of the body can give an indication of cultural activity, whether contemporary with the body or relating to earlier or later activity, such as trackways, platforms, or artefacts. For example, the trackway on Bjældskovdal bog provides evidence that the bog was being used in the centuries before the 
deposition of the bodies, and might relate to activities such as peat cutting. The contemporaneity of these features in relation to the bodies, as well as the purpose of such activities, whether for fuel or bog-ore, can also provide valuable data for interpretation. Alongside the potential for further finds, fieldwork should also include systematic survey of the bog surface and ditches.

\section{Macro-scale resolution}

Macro-scale analysis aims to understand bogs and the bodies found in them within a broader context, including the relationships between dryland and wetland. From a palaeoenvironmental perspective, the intention is to understand the development and diachronic extents of the entire peatland within its wider landscape context, including vegetation patterns across the adjacent dryland. In order to achieve this, wider borehole surveys, possibly in association with GPR survey, are required to establish the shape of the entire pre-peat land surface as well as peat stratigraphy through time. In order to reconstruct large-scale vegetation patterns and understand wider environmental factors and processes across time, the analysis of samples should include pollen, beetles and tephra, in addition to other proxies. The wider geomorphological landscape provides a context for this through various types of datasets including those obtained by LiDAR. In many regions, basic geomorphological and geological maps will already be available, which may be augmented by additional fieldwork.

In tandem with palaeoenvironmental analyses, the archaeological record should be integrated within the study. In order to assess the position of the body site in relation to contemporary cultural activity, it is important to reconstruct the character of the cultural landscape at the time of deposition. In well-investigated regions this can be done by making inventories of known sites, in combination with new excavation and survey, as appropriate. Aerial photography, LiDAR and other remote sensing methods may provide additional data on land-use patterns. For later (medieval and post medieval) bog bodies, historical sources, place names, folklore, and even oral accounts may be a valuable source of additional evidence (Kama, 2016). Equally, the detailed perusal of antiquarian records may provide additional information relating to less well-known finds from these landscapes (e.g. Cowie et al., 2011).

Analysing wider patterns of cultural continuity or change can produce information on societal changes which may provide significant information on the underlying motives of the deposition practices. Both in Yde and Borremose, the bog bodies are contemporary with the 
emergence and use of extremely rare types of walled enclosures, for example, and some form of relation between both is worthy of consideration. Equally, such patterns can be compared with factors such as environmental change to establish potential chronological and spatial relationships between the two. Hence, the investigation of bogs at this macro-scale facilitates an extension of the research agenda beyond the different approaches typically used on either wetland or dryland sites; it has the potential to integrate and understand longer-term trends in the cultural and environmental records within the vicinity of bog landscapes.

\section{DISCUSSION}

The best practice guidelines proposed provide a new framework for the study of European bog bodies which aims to ensure that future discoveries are adequately investigated, and facilitates and optimizes the re-analysis of previous discoveries. Ultimately, by using the scalar approach outlined here, it should enable different sites to be compared more explicitly. So far, most work on the landscape setting of bog bodies has been undertaken in Ireland, the United Kingdom, Denmark, and Germany. Most attention has been paid to finds dated to the Iron Age and Roman period, the medieval find of Tumbeagh in Ireland (Bermingham \& Delaney, 2006) being a notable exception. The discussion would greatly benefit from including sites from other regions (e.g. north-eastern Europe) and periods.

Not every future study will be able to encompass all scales and use all proposed methodologies. To a degree, we anticipate a mix of data collection methods based on the site location, condition, etc.: finds situated in landscapes that are heavily affected by peat-cutting and other reclamation are, as in the past, likely to form the greater part of future discoveries. Cut-over peatlands may offer limited possibilities for palaeoenvironmental study, but survey of such contexts may reveal surviving areas of contemporaneous deposits, even if those at the findspot have been disturbed or removed. For many bogs across north-western Europe, peatcutting has reduced, with many sites being restored as sites of nature conservation. Whilst new discoveries are likely to emerge through active peat milling where it is still taking place, shifts in land-use, such as re-watering, may offer new opportunities but also new challenges.

Detailed insights in archaeological site distribution patterns and, therefore, in the cultural landscape before, during, and after the time of deposition of a bog body will usually be available. The site of Yde in the Netherlands is a clear example. For new discoveries in areas where peat is still being cut, this cultural landscape context may be more difficult to reconstruct but these sites offer great chances for state-of-the-art palaeoenvironmental research as demonstrated at Old Croghan in Ireland (Plunkett et al., 2009) and Uchte in 
Germany (Bauerochse et al., 2018). However, the remaining organic resource is finite and threatened, and so there is a significant need to act quickly in order to maximize the information available.

Many research deficits signalled in this article do not only apply to bog bodies, but also to other types of archaeological finds from peatlands. These problems may partly stem from a deep-rooted distinction between wetland and dryland archaeology. Additionally, as mentioned by Brück (1999), archaeologists have the tendency to distinguish 'ritual' from 'secular' action. This leads to a misapprehension of prehistoric rationality; both are likely to have been extensively interwoven, as bog bodies being placed into peat cuttings perhaps indicate. It is important to break down the forced boundaries between the ritual and the profane, between wetland and dryland, and between scientific and cultural archaeologies to move the discussion forward, and the best practices defined here may be one of the steps contributing to that process.

\section{CONClusions}

This article has highlighted the challenges and opportunities offered through a new approach to the study of European bog bodies. We argue that the landscape context of the body constitutes an approach that may significantly improve our understanding of the individuals represented and the themes and variations within the bog body phenomenon. By assessing the current state of research and combining it with the experiences gained in three recent casestudies, this article proposes guidelines for best practice. Three spatial and temporal scales are distinguished and linked to specific research scales and methods. This provides a framework for the investigation of future discoveries, facilitates and optimizes the re-analysis of known findspots, and enables the comparison of deposition sites across time and space. It is of critical importance that such a methodology is applied to bogs before the surviving, often very fragmentary, peat resource is lost.

\section{ACKNOWLEDGEMENTS}

Roy van Beek worked on this article within the framework of the Home Turf Project of Wageningen University and Research Centre, financed by the Dutch Organisation for Scientific Research (NWO Vidi Project, no. 276-60-003). The authors would like to thank Dr Jes Martens (University of Oslo) for permission to reproduce Figure 2 and for knowledge exchange on Danish sites, and Dr Andreas Bauerochse (Lower Saxony State Office for Cultural Heritage) who provided information on his work on the Uchter Moor. 


\section{REFERENCES}

Armstrong, K., Cheetham, P. \& Darvill, T. 2018. Tales from the Outer Limits:

Archaeological Geophysical Prospection in Lowland Peat Environments in the British

Isles. Archaeological Prospection, 2018: 1-11. https://doi.org/10.1002/arp.1725

Asingh, P. 2007. The Bog People. In: P. Asingh \& N. Lynnerup, eds. Grauballe Man. An

Iron Age Bog Body Revisited. Moesgaard: Jutland Archaeological Society, pp. 290-315.

Asingh, P. \& Lynnerup, N., ed. 2007. Grauballe Man. An Iron Age Bog Body Revisited.

Moesgaard: Jutland Archaeological Society.

Bandel, J., Brennan, A., Halice, H., van der Meulen, K., Nicolay, J., Rooke, M. et al. 1995. Speurtocht naar de vindplaats van 'het meisje van Yde'. Paleo-aktueel, 6: 94-95.

Barber, K.E. 1995. Peat Stratigraphy and the Lindow Bog Body: A Reconsideration of the Evidence. In: R.C. Turner \& R.G. Scaife, eds. Bog Bodies. New Discoveries and New Perspectives. London: British Museum, pp. 50-51.

Bauerochse, A. \& Niemuth, A. 2012. 3D-Landschaftsmodellierung und Umweltrekonstruktion. Telma, 42: 19-26. https://doi.org/10.23689/fidgeo-2958

Bauerochse, A., Haßmann, H., Püschel, K. \& Schultz, M., eds. 2018. 'Moora' - Das Mädchen aus dem Uchter Moor: Eine Moorleiche der Eisenzeit aus Niedersachsen II. Naturwissenschaftliche Ergebnisse (Materialhefte zur Ur- und Frühgeschichte Niedersachsens 47). Rahden: Marie Leidorf.

Becker, K. 2013. Transforming Identities. New Approaches to Bronze Age Deposition in Ireland. Proceedings of the Prehistoric Society, 79: 225-63. https://doi.org/10.1017/ppr.2013.8

Bermingham, N. \& Delaney, M. 2006. The Bog Body from Tumbeagh. Bray: Wordwell.

Birks, H.J.B. 1965. Pollen Analytical Investigations at Holcroft Moss, Lancashire and Lindow Moss, Cheshire. Journal of Ecology, 53: 299-314.

Bottema, S., 1995: Het ontstaan van het veentje van het meisje van Yde (Dr.). Paleo-aktueel, 6: 96-98.

Bradley, R. 2000. An Archaeology of Natural Places. London \& New York: Routledge.

Branch, N.P. \& Scaife, R.G. 1995. The Stratigraphy and Pollen Analysis of Peat Sequences Associated with the Lindow III Bog Body. In: R.C. Turner \& R.G. Scaife, eds. Bog Bodies. New Discoveries and New Perspectives. London: British Museum, pp. 19-30.

Bronk Ramsey C. 2009. Bayesian Analysis of Radiocarbon Dates. Radiocarbon, 51: 337-60. https://doi.org/10.1017/S0033822200033865 
Brothwell, D. 1986. The Remains of Lindow Woman. In: I.M. Stead, J.B. Bourke \& D. Brothwell, eds. Lindow Man. The Body in the Bog. London: British Museum, pp. 52-53. Brothwell, D. \& Gill-Robinson, H. 2002. Taphonomic and Forensic Aspects of Bog Bodies. In: W.D. Haglund \& M.H. Sorg, eds. Advances in Forensic Taphonomy. Method, Theory, and Archaeological Perspectives. Boca Raton, London, New York \& Washington D.C.: CRC Press, pp. 119-32.

Brück, J. 1999: Ritual and Rationality: Some Problems of Interpretation in European Archaeology. European Journal of Archaeology, 2: 313-44. https://doi.org/10.1179/eja.1999.2.3.313

Buckland, P.C. 1995. Peat Stratigraphy and the Age of the Lindow Bodies. In: R.C. Turner \& R.G. Scaife, eds. Bog Bodies. New Discoveries and New Perspectives. London: British Museum, pp. 47-50.

Burmeister, S. 2013. Moorleichen - Sonderbestattung, Strafjustiz, Opfer? Annäherungen an eine kulturgeschichtliche Deutung. In: N. Müller-Scheeßel, ed. 'Irreguläre’ Bestattungen in der Urgeschichte: Norm, Ritual, Strafe...? Frankfurt: Römisch-Germanische Kommission des Deutschen Archäologischen Instituts, pp. 485-506.

Chapman, H. 2015. The Landscape Archaeology of Bog Bodies. Journal of Wetland Archaeology, 15: 109-21. https://doi.org/10.1080/14732971.2015.1112592

Chapman, H.P. \& Gearey, B.R. 2013. Modelling Archaeology and Palaeoenvironments in Wetlands. The Hidden Landscape Archaeology of Hatfield and Thorne Moors, Eastern England. Oxford: Oxbow.

Clarke, C.M., Utsi, E. \& Utsi, V. 1999. Ground Penetrating Radar Investigations at North Ballachulish Moss, Highland, Scotland. Archaeological Prospection, 6: 107-21. https://doi.org/10.1002/(SICI)1099-0763(199906)6:2<107::AID-ARP121>3.0.CO;2-0

Cowie, T., Pickin, J. \& Wallace, C. 2011. Bog Bodies from Scotland: Old Finds, New Records. Journal of Wetland Archaeology, 10: 1-45. https://doi.org/10.1179/jwa.2011.10.1.1

Fischer C. 1980. Moseligene fra Bjældskovdal. KUML, Årbog for Jysk Arkaoologisk Selskab, 1979: 7-44.

Fischer, C. 2012. Tollund Man. Gift to the Gods. Stroud: The History Press.

Fontijn, D.R. 2002. Sacrificial Landscapes. Cultural Biographies of Persons, Objects and 'Natural' Places in the Bronze Age of the Southern Netherlands, c. 2300-600 BC (Analecta Praehistorica Leidensia 33/34). Leiden: University of Leiden. 
Fredengren, C. 2018. Becoming Bog Bodies: Sacrifice and Politics of Exclusion, as Evidenced in the Deposition of Skeletal Remains in Wetlands. Journal of Wetland Archaeology, 18: 1-19. https://doi.org/10.1080/14732971.2017.1408596

Gearey, B.R. \& Caseldine, C.J. 2006. Archaeological Applications of Testate Amoebae Analyses: A Case Study from Derryville, Co. Tipperary, Ireland. Journal of Archaeological Science, 33: 49-55. https://doi.org/10.1016/j.jas.2005.06.005

Gearey, B.R. \& Chapman, H.P. 2004. Towards Realising the Full Archaeo-environmental Potential of Raised (Ombrotrophic) Mires in the British Isles. Oxford Journal of Archaeology, 23: 199-208. https://doi.org/10.1111/j.1468-0092.2004.00209.x

Gill-Robinson, H.C. 2005. The Iron Age Bog Bodies of the Archaeologisches Landesmuseum, Schloss Gottorf, Schleswig, Germany. Unpublished PhD dissertation, University of Manitoba, Winnipeg.

Glob, P.V. 1969. The Bog People. Iron Age Man Preserved. London: Faber \& Faber.

Hesse, S., Grefen-Peters, S., Peek, C., Rech, J. \& Schliemann, U. 2010. Die Moorleichen im Landkreis Rotenburg (Wümme): Forschungsgeschichte und neue Untersuchungen. Archäologische Berichte des Landkreises Rotenburg (Wümme), 16: 31-88.

Kama, P. 2016. Place-lore Concerning Bog Bodies and a Bog Body Concerning Place-lore. Journal of Wetland Archaeology, 16: 1-16. https://doi.org/10.1080/14732971.2016.1215664

Kelly, E.P. 2006. Secrets of the Bog Bodies: The Enigma of the Iron Age Explained. Archaeology Ireland, 20: 26-30.

Kelly, E.P. 2012. An Archaeological Interpretation of Irish Iron Age Bog Bodies. In: S. Ralph, ed. The Archaeology of Violence. Interdisciplinary Approaches. New York: State University of New York Press, pp. 232-40.

Leah, M.D., Wells, C.E., Appleby, C. \& Huckerby, E. 1997. The Wetlands of Cheshire (Lancaster University Archaeological Unit, North West Wetlands Survey 4). Lancaster: Lancaster University.

Martens, J. 1994. Refuge - Fortified Settlement - Central Place? Three Years of Archaeological Investigations at the Borremose Stronghold (1988-1991), an Enclosed Settlement from the Pre-Roman Iron Age of Himmerland. EthnographischArchäologische Zeitschrift, 35: 241-73.

Needham, S. 1988: Selective Deposition in the British Early Bronze Age. World Archaeology, 20: 229-48. 
Nielsen, N.H., Philippsen, B., Kanstrup, M. \& Olsen, J. 2018. Diet and Radiocarbon Dating of Tollund Man - New Analyses of an Iron Age Bog Body from Denmark. Radiocarbon, 60: 1533-45. https://doi.org/10.1017/RDC.2018.127

Norbury, W.H. 1884. Lindow Common as a Peat Bog: Its Age and its People. Transactions of the Lancashire and Cheshire Antiquarian Society, 2: 59-75.

Oldfield, F., Higgitt, S.R., Richardson, N. \& Yates, G. 1986. Pollen, Charcoal, Rhizopod and Radiometric Analyses. In: I.M. Stead, J.B. Bourke \& D. Brothwell, eds. Lindow Man. The Body in the Bog. London: British Museum, pp. 82-85.

Plunkett, G., Whitehouse, N.J., Hall, V.A., Charman, D.J., Blaauw, M., Kelly, E. \& Mulhall, I. 2009. A Multi-proxy Palaeoenvironmental Investigation of the Findspot of an Iron Age Bog Body from Oldcroghan, Co. Offaly, Ireland. Journal of Archaeological Science, 36: 265-77. https://doi.org/10.1016/j.jas.2008.09.014

Ravn, M., 2010. Burials in Bogs. Bronze and Early Iron Age Bog Bodies from Denmark. Acta Archaeologica, 81: 106-17. https://doi.org/10.1111/j.1600-0390.2010.00307.x

Ravn, M. 2011. Bog Bodies - A Burial Practice During the Early Iron Age? In: L. Boyle, ed. The Iron Age on Zealand: Status and Perspectives (Nordiske fortidsminder 8). Copenhagen: Royal Society of Northern Antiquaries, pp. 83-89.

Reimer, P.J., Bard, E., Bayliss, A., Beck, J.W., Blackwell, P.G., Bronk Ramsey, C. et al. 2013. IntCal13 and Marine13 Radiocarbon Age Calibration Curves 0-50,000 Years cal BP. Radiocarbon, 55: 1869-87. https://doi.org/10.2458/azu_js_rc.55.16947

Schleifer, N., Weller, A., Schneider, S. \& Junge, A. 2002. Investigation of a Bronze Age Plankway by Spectral Induced Polarisation. Archaeological Prospection, 9: 243-53. https://doi.org/10.1002/arp.194

Troels-Smith, J. 1952. Untitled field note book relating to stratigraphic analysis and sampling at Bjaeldskovdal. National Museum of Denmark, Copenhagen (Archive Number A4020)..

Turner, R.C. 1986. Discovery and Excavation of the Lindow Bodies. In: I.M. Stead, J.B.

Bourke \& D. Brothwell, eds. Lindow Man. The Body in the Bog. London: British Museum, pp. 10-13.

Turner, R.C. 1995. The Lindow Bog Bodies. In: R.C. Turner \& R.G. Scaife, eds. Bog Bodies. New Discoveries and New Perspectives. London: British Museum, pp. 10-18.

van Beek, R., Maas, G.J. \& van den Berg, E. 2015. Home Turf: An Interdisciplinary Exploration of the Long-term Development, Use and Reclamation of Raised Bogs in the Netherlands. Landscape History, 36: 5-34. 
van Beek, R., Candel, J.H.J., Quik, C., Bos, J.A.A., Gouw-Bouman, M.T.I.J., Makaske, B. \& Maas, G.J. 2019 (online first): The Landscape Setting of Bog Bodies: Interdisciplinary Research into the Site Location of Yde Girl, The Netherlands. The Holocene, https://doi.org/10.1177/0959683619838048

van der Plicht, J., van der Sanden, W.A.B., Aerts, A.T. \& Streurman, J.J. 2004. Dating Bog

Bodies by Means of ${ }^{14} \mathrm{C}$-AMS. Journal of Archaeological Science, 31: 471-91.

https://doi.org/10.1016/j.jas.2003.09.012

van der Sanden, W.A.B., 1990. Mens en moeras. Veenlijken in Nederland van de Bronstijd tot en met de Romeinse tijd. Assen: Drents Museum.

van der Sanden, W.A.B., 1994. Het meisje van Yde. Assen: Drents Museum.

van der Sanden, W.A.B. 1996. From Nature to Eternity. The Bog Bodies of Northwest

Europe. Amsterdam: Batavian Lion International.

van der Sanden, W.A.B. 2013. Bog Bodies: Underwater Burials, Sacrifices and Executions.

In: F. Menotti \& A. O’Sullivan, eds. The Oxford Handbook of Wetland Archaeology.

Oxford: Oxford University Press, pp. 401-16.

West, I.E. 1986. Forensic Aspects of Lindow Man. In: I.M. Stead, J.B. Bourke \& D.

Brothwell, eds. Lindow Man. The Body in the Bog. London: British Museum, pp. 77-80.

\section{BIOGRAPHICAL NOTES}

Henry Chapman is Professor of Archaeology at the University of Birmingham, UK. His research interests centre on wetland archaeology, later prehsitory and the application of digital technologies and modelling for understanding the past. Henry has worked extensively on wetand sites and landscapes and, most recently, on sites of bog body deposition in the UK and Denmark.

Address: Henry Chapman, Department of Classics, Ancient History and Archaeology, Arts Building, University of Birmingham, Edgbaston, Birmingham, B15 2TT, UK. [email: h.chapman@bham.ac.uk] ORCID-0000-0001-8677-7950

Roy van Beek is an assistant professor in landscape archaeology at the Soil Geography \& Landscape Group and Cultural Geography Group of Wageningen University. His main interests are in the reconstruction of long-term landscape dynamics and human-landscape interactions, especially in wetland environments, and in the application of these insights in heritage management. 
Address: Roy van Beek, Departement Omgevingswetenschappen, Wageningen University and Research, Postbus 47, 6700AA Wageningen, The Netherlands. [email: roy.vanbeek@wur.nl] ORCID: 0000-0002-0726-6974

Ben Gearey is a lecturer in Archaeology at Univeristy College Cork. Ben completed his $\mathrm{PhD}$ at the University of Plymouth, focussing on human-environment relatiosn on Bodmin moor during the Holocence. He has research interests in wetland archaeology and palaeoenvironments, environmental archaeology, the geoarchaeology of alluvial landscapes, and the formulation of heritage policy.

Address: Ben Gearey, Department of Archaeology, University College Cork, Connolly Building, Dyke Parade, University College Cork, Cork City, T12 CY82, Ireland. [email: b.gearey@ucc.ie] ORCID: 0000-0003-0323-4921

Ben Jennings is a lecturer in Archaeology at the University of Bradford. He completed his $\mathrm{PhD}$ at the University of Basel, studying lake-dwellings of the Alpine region. His research interests focus on wetland settlement and exploitation in prehistory, and the modelling of exchange and interaction systems.

Address: Ben Jennings, School of Archaeological and Forensic Sciences, Univeristy of Bradford, Richmond Road, Bradford, BD7 1DP, UK. [email: b.r.jennings@ @bradford.ac.uk] ORCID: 0000-0003-2130-5746

David Smith is a senior lecturer in the Department of Classics, Ancient History and Archaeology at the University of Birmingham. His research specialism is in Archaeoentomology. David has undertaken research on the reconstruction of a range of Holocene landscapes using insect remains and how insects can be used to understand the development and interpretation of past human settlement. David Smith also offers commercial archaeoentomological services to a range of heritage and archaeological providers. 
Address: David Smith, Department of Classics, Ancient History and Archaeology, University of Birmingham, Edgbaston, Birmingham, B15 2TT, UK. [email: d.n.smith@bham.ac.uk] ORCID: 0000-0002-5589-7201

Nina Helt Nielsen is Head of Research at Museum Silkeborg. Nina completed her PhD on 'Formation of Celtic Fields: A geoarchaeological and relativechronological study of selected Danish field systems from the Late Bronze and Early Iron Age'. She is interested in geoarchaeology and how archaeological science can contribute to the understanding of prehistoric societies. She continues her research on Celtic fields, but is also involved in other research projects at Museum Silkebog, including studies of Tollund Man.

Address: Nina Helt Nielsen, Museum Silkeborg, Hovedgården, Hovedgårdsvej 7, DK-8600 Silkdeborg, Denmark. [email: nhn@museumsilkeborg.dk] ORCID: 0000-0001-6700-6528

Zena Zein Elabdin is a doctoral student at the University of Birmingham having completed a BA in Ancient History and an MA in Landscape Archaeology. Zena's doctoral research focuses on the landscapes of Lindow Moss in England and Bjældskovdal bog in Denmark, investigating the broader landscape context of the deposition of Lindow II and Tollund Man. She is interested in the deposition of skulls in wetland landscapes, wetland archaeology and developing her digital software skills to model past landscapes.

Address: Zena Zein Elabdin, Department of Classics, Ancient History and Archaeology, University of Birmingham, Edgbaston, Birmingham, B15 2TT, UK. [email: ZMZ030@student.bham.ac.uk] ORCID: 0000-0003-4582-6853

\section{Le contexte des corps des tourbières : élaboration de lignes directrices pour une pratique exemplaire}

Les corps des tourbières figurent parmi les découvertes les plus célèbres du monde. Les études utilisant des techniques médico-légales constituent une large part des recherches menées sur ces vestiges humains souvent très bien conservés mais le milieu dans lequel ces découvertes ont été faites a été largement négligé. Ceci vaut tout autant pour le milieu physique que pour l'environnement culturel et constitue un problème considérable, étant donné que cette pratique de déposition de corps se manifeste sur une vaste échelle temporelle et spatiale ; l'évaluation 
du contexte est donc d'importance primordiale pour nos modèles d'interprétation. Les auteurs de cet article proposent des lignes directrices de pratique exemplaire visant à analyser les momies des tourbières dans leur contexte à partir d'une synthèse sur l'état actuel des recherches et d'une présentation de trois études de cas récentes concernant l'Homme de Lindow en Angleterre, Bjaldskovdal au Danemark (Homme de Tollund et Femme d'Elling) et la Fille d'Yde aux Pays-Bas. Les auteurs identifient trois échelles spatiales et chronologiques liées à des questions de recherche et de méthode spécifiques. Ces lignes directrices peuvent servir de base à des discussions plus approfondies et à la mise en pratique de stratégies permettant de mieux comprendre les corps des tourbières connus et encore à découvrir, de réexaminer les résultats d'études antérieures et ainsi de comparer les sites de dépôts à travers le temps et l'espace. Translation by Madeleine Hummler

Mots-clés : corps des tourbières, Europe, paysage, analyse multiscalaire, tourbières, emplacements de sites

\section{Moorleichen im Kontext: Entwicklung von Richtlinien für eine beste Praxis}

Die Moorleichen gehören zu den bekanntesten archäologischen Funden in der ganzen Welt. Meist haben sich die Untersuchungen von diesen oft außergewöhnlich gut erhaltenen Menschenresten aufforensische Aspekte konzentriert, während die Umgebung der Fundstätten weitgehend unbeachtet geblieben ist. Das gilt sowohl für die, physische' sowie für die kulturelle Landschaft und stellt ein wesentliches Problem dar, weil die zeitlich und räumlich sehr weit verbreiteten Moordeponierungen zeigen, dass die Beurteilung deren Kontexte von höchster Bedeutung für unsere Erklärungsmodelle ist. In diesem Artikel werden Richtlinien für eine beste Praxis der Kontextanalyse von Moorleichen vorgeschlagen; dies folgt eine Bewertung des aktuellen Forschungsstandes und eine Darstellung von drei neueren Fallstudien, die den Lindow-Mann in England, die Moorleichen von Bjaldskovdal in Dänemark (Tollund-Mann und Frau von Elling) und das Mädchen von Yde in den Niederlanden betreffen. Man kann zwischen drei zeitlichen und räumlichen Skalen unterscheiden und diese mit bestimmten Fragestellungen und Methoden der Forschung verknüpfen. Solch ein Verfahren bildet die Grundlage für weitere Diskussionen und ein Ansatzpunkt für die Entwicklung von neuen Ansätzen in der Erforschung von bekannten und zukünftigen Moorleichen, erleichtert sowie optimiert die Neubewertung von älteren Untersuchungen und ermöglicht zeitliche und räumliche Vergleiche zwischen verschiedenen Moordeponierungen. Translation by Madeleine Hummler 
Stichworte: Moorleichen, Europa, Landschaft, Skalenanalyse, Moore, Lage der Fundplätze

\section{Figure captions}

Figure 1. Locations of the principal sites mentioned in the text including the three case studies.

Figure 2. Cultural landscape of the Borremose region (Denmark) in the Iron Age. The indicated wetland areas at this time, mostly consisting of peatlands, are mainly derived from modern-day geomorphological and elevation data.

Redrawn after Martens, 1994: 267, fig. 19, with permission of the author.

Figure 3. Lindow Moss, Cheshire (UK), showing the locations of the three bog body finds. Left: topography of the pre-peat land surface; Right: extrapolated extents of wetland at the time of deposition of the Lindow II body.

Figure 4. Bjoeldskovdal (Denmark), showing the positions of the three bog body finds and extrapolated extents of wetland at the time of deposition of Tollund Man (plan and profile).

Figure 5. Cultural landscape of the Yde microregion during the Late Iron Age/Early Roman period (250 BC to AD 100). Geomorphological map by Gilbert Maas (Wageningen Environmental Research) and Bart Makaske (Wageningen University \& Research Centre). Figure 6. Schematic representation of the different spatial research scales to be included in future bog body research, and how they relate to the different temporal scales in terms of time depth. 


\section{Table}

Table 1. The three spatial and temporal scales to be included in future bog body research, and the ways in which they relate to themes of interpretation.

\begin{tabular}{|c|c|c|c|}
\hline SCALE & SPATIAL & CHRONOLOGICAL & INTERPRETATIVE SIGNIFICANCE \\
\hline \multicolumn{4}{|l|}{ MICRO } \\
\hline $\mathrm{ARCH}$ & $\begin{array}{l}\text { Precise context of } \\
\text { deposition (e.g. turf, } \\
\text { pool) and related } \\
\text { stratigraphy } \\
\text { Other } \\
\text { objects/material (e.g. } \\
\text { withies, hurdles) }\end{array}$ & $\begin{array}{l}\text { Date of body and of } \\
\text { associated immediate } \\
\text { context (century scale } \\
\text { plus) }\end{array}$ & $\begin{array}{l}\text { Character of site of deposition; related } \\
\text { issues including accessibility. Forensic } \\
\text { analysis of body. Function/role of other } \\
\text { materials/items associated with the } \\
\text { deposition of the body }\end{array}$ \\
\hline \multicolumn{4}{|l|}{ MESO } \\
\hline $\mathrm{ARCH}$ & $\begin{array}{l}\text { Site of deposition } \\
\text { within context of the } \\
\text { wider wetland } \\
\text { system; longer-term } \\
\text { patterns of wetland } \\
\text { development and } \\
\text { change } \\
\text { Evidence for other } \\
\text { forms of } \\
\text { archaeological } \\
\text { remains representing } \\
\text { activity in wetland } \\
\text { (e.g. trackways, } \\
\text { platforms) }\end{array}$ & $\begin{array}{l}\text { Timing of development } \\
\text { of wetland system } \\
\text { (century to millennial } \\
\text { scale) in relation to the } \\
\text { deposition of the body } \\
\\
\text { Duration/tempo of any } \\
\text { such cultural activity in } \\
\text { wetland system over } \\
\text { century to millennial } \\
\text { scale }\end{array}$ & $\begin{array}{l}\text { Establishing potential links between } \\
\text { patterns and processes of wetland change } \\
\text { (e.g. bog inception and growth) and } \\
\text { possible autogenic factors (climate } \\
\text { change). Anthropogenic activity reflecting } \\
\text { use and perception of wetland through } \\
\text { time to contextualize the deposition of the } \\
\text { body }\end{array}$ \\
\hline \multicolumn{4}{|l|}{ MACRO } \\
\hline $\mathrm{ARCH}$ & $\begin{array}{l}\text { Longer-term } \\
\text { evolution of findspot } \\
\text { in relation to wetland } \\
\text { development as } \\
\text { above, with evidence } \\
\text { for terrestrial dryland } \\
\text { environmental } \\
\text { changes } \\
\text { Terrestrial } \\
\text { archaeology; patterns } \\
\text { character and } \\
\text { distribution (e.g. } \\
\text { settlements, } \\
\text { excavated sites) }\end{array}$ & $\begin{array}{l}\text { Tempo and character of } \\
\text { human activity on } \\
\text { dryland plus other } \\
\text { regional wetland areas if } \\
\text { relevant }\end{array}$ & $\begin{array}{l}\text { Evidence for longer-term and broader } \\
\text { spatial patterns of change to meso-/micro- } \\
\text { scale, i.e. relationship between wider } \\
\text { patterns of environmental change and } \\
\text { wetland development, woodland } \\
\text { clearance, agriculture and climatic } \\
\text { changes. Locating body within broader } \\
\text { patterns of cultural and social activity and } \\
\text { change on both wetland and dryland }\end{array}$ \\
\hline
\end{tabular}

